\title{
ON THE PULSATING EVOLUTION OF THE MEDITERRANEAN
}

by

Johan E. Meulenkamp

\begin{abstract}
Many biostratigraphic and chronostratigraphic concepts as well as theories on geodynamic evolution have originated from studies of Mediterranean rock sequences. In terms of geodynamic evolution it now seems unlikely that the present configuration of the area is the result of gradual, sustained changes over tens of millions of years. This has led to a revival of some of the classical ideas on episodicity of tectonic movements. Since a well-tested and accurate biostratigraphic-chronostratigraphic scheme is available for the Cenozoic of the Mediterranean area, stratigraphers are able to establish a model of geotectonic events in time by analyzing and interpreting sedimentary events. Such an exercise has been carried out for the uppermost Eocene to Pliocene of some parts of the Mediterranean.
\end{abstract}

\section{The Hellenic and Calabro-Sicilian Arcs}

The Hellenic and Calabro-Sicilian arcs form part of the young Alpine mountain chains of the Mediterranean (Fig. 1). The outlines of the geological history of the arcs are fairly well known (Angelier, 1979; Aubouin, 1973; Caire, 1973; Closs, 1978; Dercourt et al., 1977; Ogniben, 1969; and Ogniben and Vezzani, 1975).

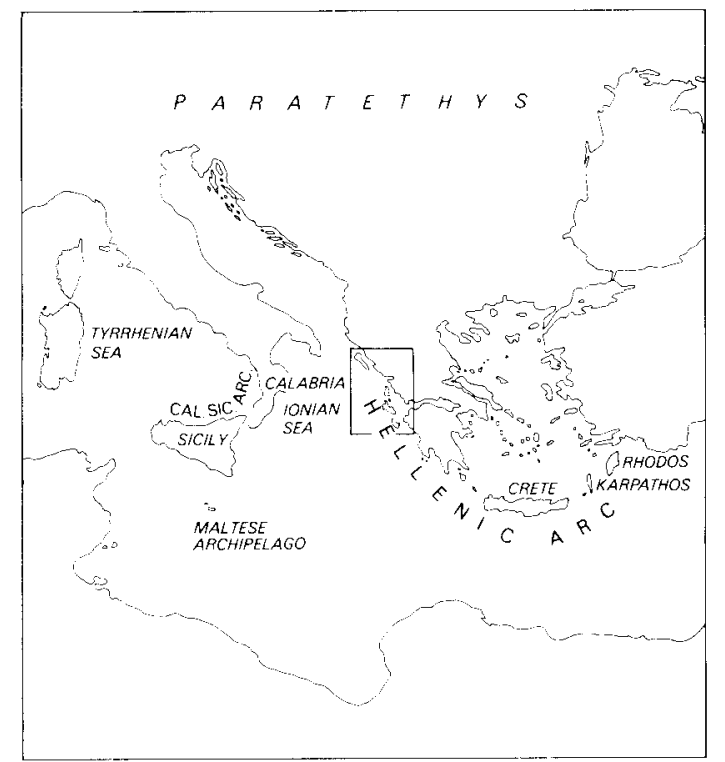

Figure 1. Part of the Mediterranean-Paratethyan realm. Square indicates position of area of Fig. 3.

In a paper given at the International Symposium on the Hellenic Arc and Trench, Athens, 1981, the present author stressed the episodicity and contemporaneity of the major tectonic events that affected the Hellenic and CalabroSicilian arcs from the latest Eocene to the Pliocene. Detailed stratigraphic analyses by the Utrecht team of some parts of the arcs (the Ionian islands and Epirus, Crete, Sicily and Calabria, Figs. 1,3) and an evaluation of literature data indicate that rapid changes in sedimentation patterns and basin configuration in one area generally had clearly recognizable, contemporaneous counterparts in other areas. Such changes seem to have occurred during short periods of time; the corresponding tectonic movements terminated or initiated fairly lengthy periods during which either there were no major changes in the sedimentary-tectonic "regime", or changes were of secondary importance.
The most important tectonic events can be bracketed around the transitions from the Eocene to the Oligocene, from the Early to the Late Oligocene and from the oligocene to the Miocene. Other major events occurred in late Early Miocene (Late Burdigalian) time, during the (Late) Serravallian to earliest Tortonian, and in the latest Miocene to Early Pliocene interval (during the transition from the Tortonian to the Messinian, within the Messinian and in the Early Pliocene). The position of intervals with major tectonic events relative to biostratigraphic and chronostratigraphic schemes and to the radiometric scale are summarized in Figure 2.

\section{Nature and Impact of Events}

The nature of the tectonic movements and their consequences for the sedimentation and basin configuration were not the same, either in time when we consider a particular area, or in space if we consider a particular time-slice. This can be demonstrated by the chart showing the main changes in sedimentation patterns in parts of the lonian and Preapulian isopic zones of the Hellenides in NW Greece (Figs. 3,4). This article summarizes some of these changes and compares them with the effects of contemporaneous changes in basin configuration and sedimentation elsewhere in the Hellenic arc and on Sicily.

Simple block-faulting during the transition from the Early to the Late Oligocene caused increasing fragmentation of the interconnected basins of the external part of the Ionian zone. This block-faulting was accompanied by increased supply of coarse limestone debris brought by gravity-induced currents from a source area in the west. In the Preapulian zone a relative uplift can be inferred from the shift from pelagic to neritic carbonate sedimentation. Elsewhere in the Hellenic arc (on the islands of Rhodos, Karpathos and probably also Crete), the intra-Oligocene movements were far more vigorous, causing the emplacement of nappe systems or largescale, submarine gravity sliding.

Around the time of the transition from the Oligocene to the Miocene, sedimentation in the external part of the Ionian zone became characterized by the accumulation of terrigenous-clastic turbidites. Neritic carbonate sedimentation in the Preapulian zone was replaced by deposition of marlclay sequences in relatively deep water. These changes in sedimentation patterns were related to the uplift of areas in more internal parts of the orogen in the east. This uplift was balanced by the subsidence of areas in the west.

The Late Burdigalian chain of events caused dramatic changes in the paleogeography of and sedimentation in NW Greece. Movements related to thrusting caused intensive folding, uplift and erosion of the older sediment sequence in 


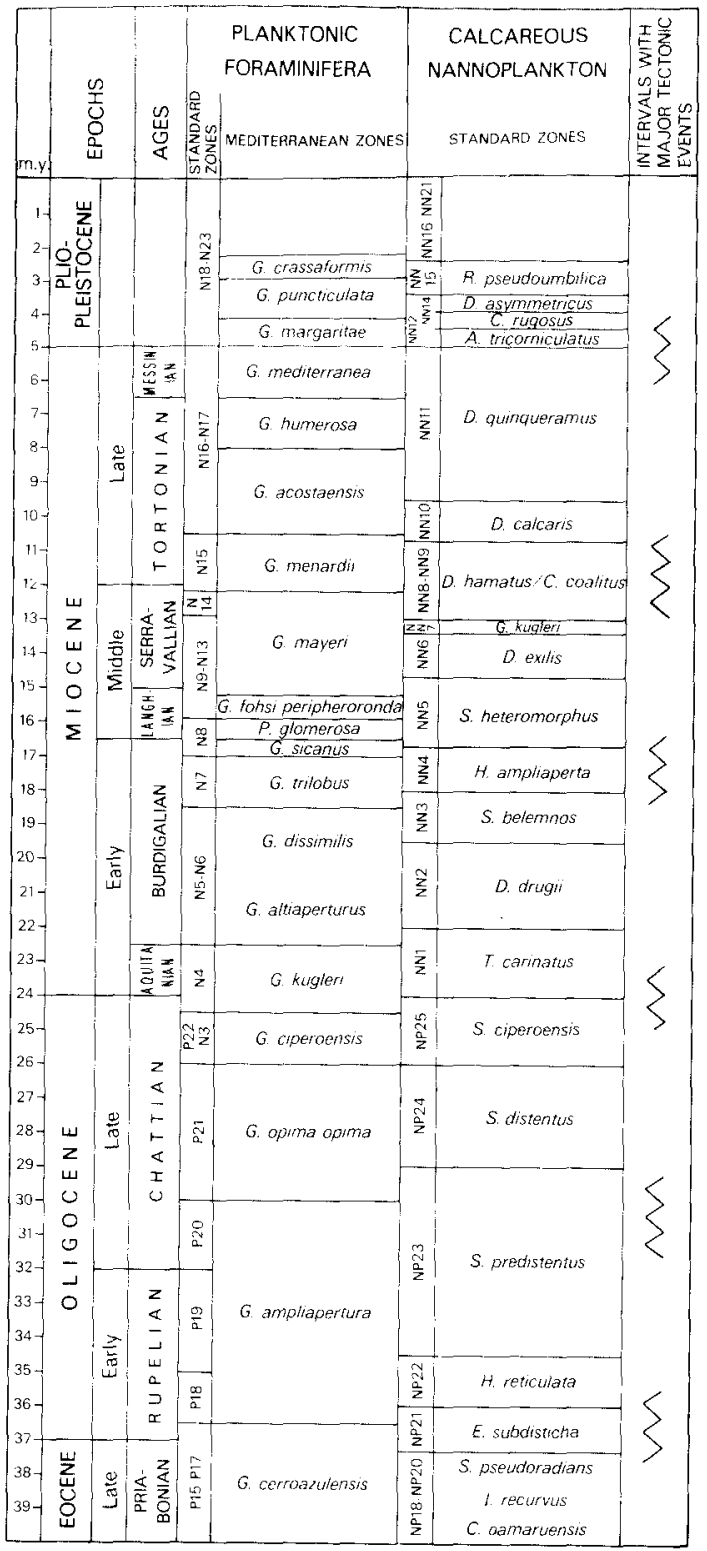

Figure 2. Diagram showing position of intervals including major tectonic events in the Hellenic and Calabro-Sicilian arcs relative to biostratigraphy and geochronology. The episodicity and periodicity of major tectonic events suggest a pulsating evolution of the arcs. The same is probably true for the entire Mediterranean and the Paratethys. Biostratigraphic scales and geochronology mainly after Bizon et al., 1979; and Hardenbol and Berggren, 1978.

the Ionian zone. These processes were followed in latest Burdigalian time by the subsidence of the base-levelled surface. In the slightly more external, eastern part of the Preapulian zone the older sediments were also strongly folded but not uplifted. Sedimentation here was continuous, although it changed abruptly from deposition of calcareous marls with clayey interbeds to deposition of (silty) clays and sands. The rugged, submarine relief resulting from the deformation of strata was filled with sediments of latest Burdigalian to earliest Langhian Age.

Along the western margin of the Preapulian zone the Late Burdigalian movements did not have much effect. A few metres of slumped, folded sediments in an undisturbed, monoclinal succession may represent the only detectable sedimentary expression of these movements. This slumping was probably caused by a temporary increase in the basinslope gradient as a result of differential, vertical movements.

By comparison, a study of the sedimentary record of Sicily indicates large differences in the effects of the Late Burdigalian to earliest Langhian period of tectonic instability as well. In SE Sicily, which at the time belonged to the socalled "stable" external platform, a relative uplift caused low rates of sedimentation and local erosion, followed by subsidence and a shift from carbonatic to exclusively terrigenousclastic sedimentation. These processes were contemporary with the emplacement of nappes and olistostromes and with a rapid increase in the subsidence rate of the Caltanisetta basin in the now adjacent, "orogenic" part of Sicily.

Movements in (Late) Serravallian to earliest Tortonian time generally resulted in fragmentation all over the Hellenic and Calabro-Sicilian arcs. Along the western margin of the Preapulian zone in NW Greece such movements caused, among other things, the shift from sedimentation of calcareous marls and clays with a superimposed supply of masstransported limestone debris to deposition of clays and sands.

Contemporaneous movements in the southern Aegean (Crete and adjacent areas) resulted in a paleogeographic revolution. The southern Aegean land mass and its bordering basin, which existed for a poorly-defined time-span during the Miocene, were transformed into a mosaic of relatively small-sized horsts and grabens. This may have been related to the beginning of the subduction of the African Plate under the European Plate (Le Pichon and Angelier, 1979).

In the Early Pliocene thrusting of the Ionian zone occurred relative to the Preapulian zone in nor th-west Greece. Blockfaulting in the Cretan area resulted in the beginning of the emergence of the island; these movements were connected with the start of a general tilting to the north and the rapid foundering of the southern Aegean basin (Fig. 5). Contemporaneous movements affecting the Calabro-Sicilian arc were related to thrusting. Down-slope transport of allochthonous masses and the development of nappe-like units were

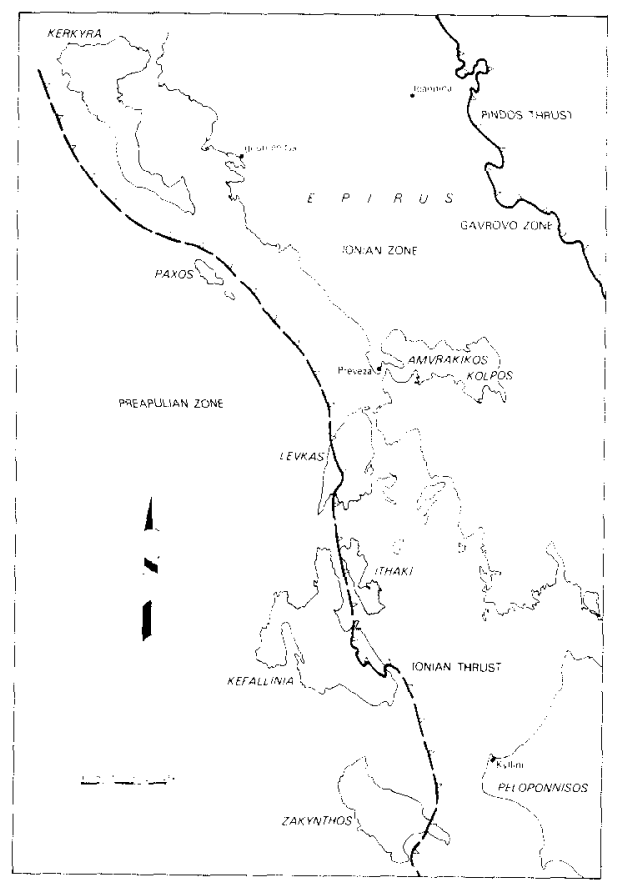

Figure 3. Schematic map of NW Greece showing position of the Ionian and Preapulian isopic zones of the Hellenides. 


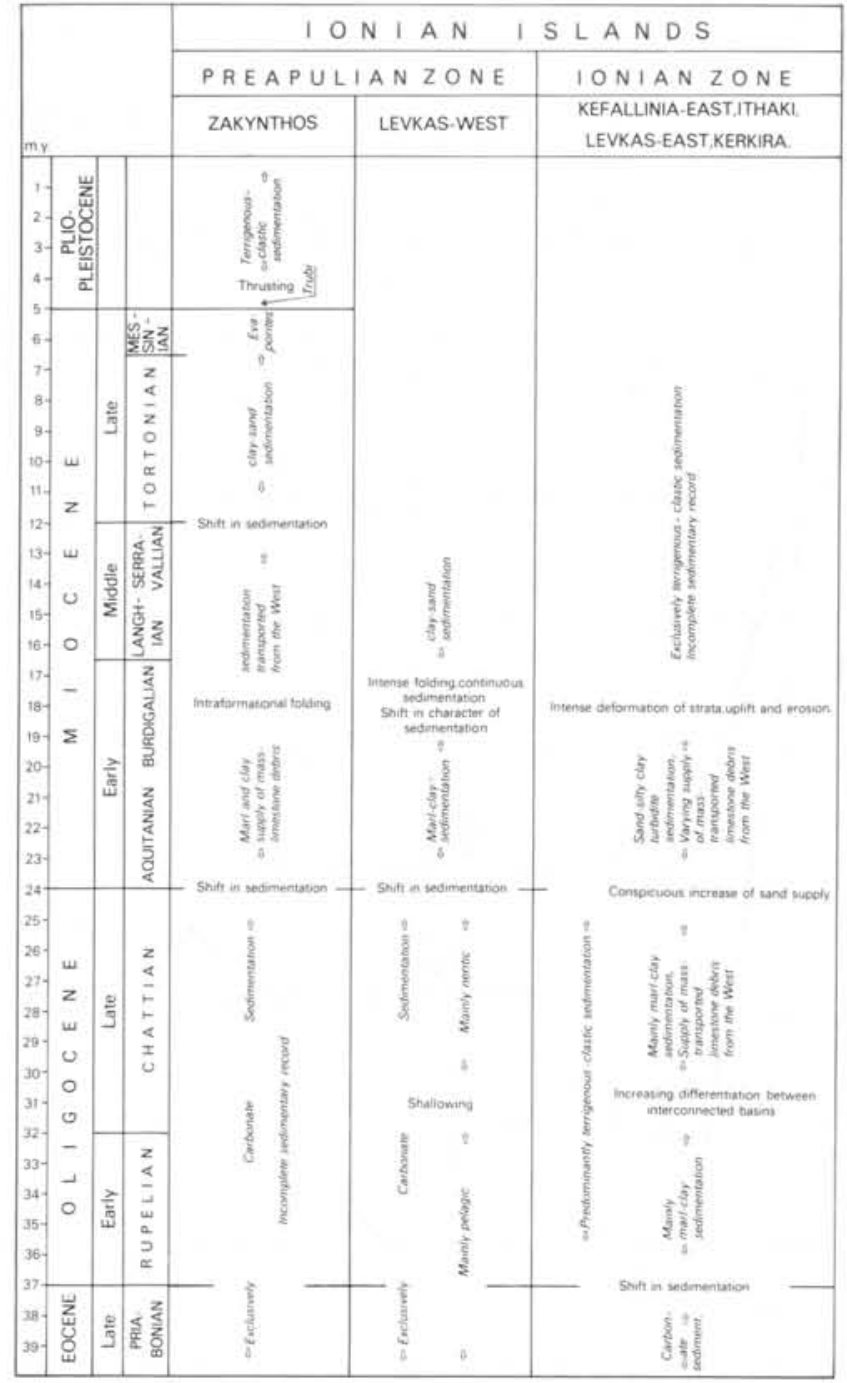

Figure 4. Chart summarizing characteristic sedimentation patterns and their changes in space and time in parts of the Ionian and Preapulian zones, NW Greece.

related to a conspicuous increase in the basin-slope gradient (Fig. 6). In this respect the large-scale gravity sliding closely resembled that connected with the Late Burdigalian phase of tectonic instability. In the course of the Plio-Pleistocene the Calabro-Sicilian arc emerged and the Tyrrhenian basin rapidly subsided to local depths of more than 3000 metres. Leftlateral strike-slip movements of the Ragusa platform (SE Sicily) relative to the Caltanisetta basin resulted in the present-day unity of Sicily.

\section{Pulsating Evolution of the Mediterranean and the Paratethys}

Our data as well as those from the literature suggest that most, if not all, of the major tectonic events inferred from the latest Eocene to Pliocene sedimentary record of the Hellenic and Calabro-Sicilian arcs had contemporaneous counterparts elsewhere in the orogenic belts of the Mediterranean area proper, in the Paratethys (Fig. 1), and in areas that were part of external platforms.

In the Paratethys, for example, the event that occurred around the transition from the Eocene to the Oligocene probably initiated the differentiation between this part of the Tethyan belt and the Mediterranean. Similarly, the intraOligocene events started the fragmentation of a large basin

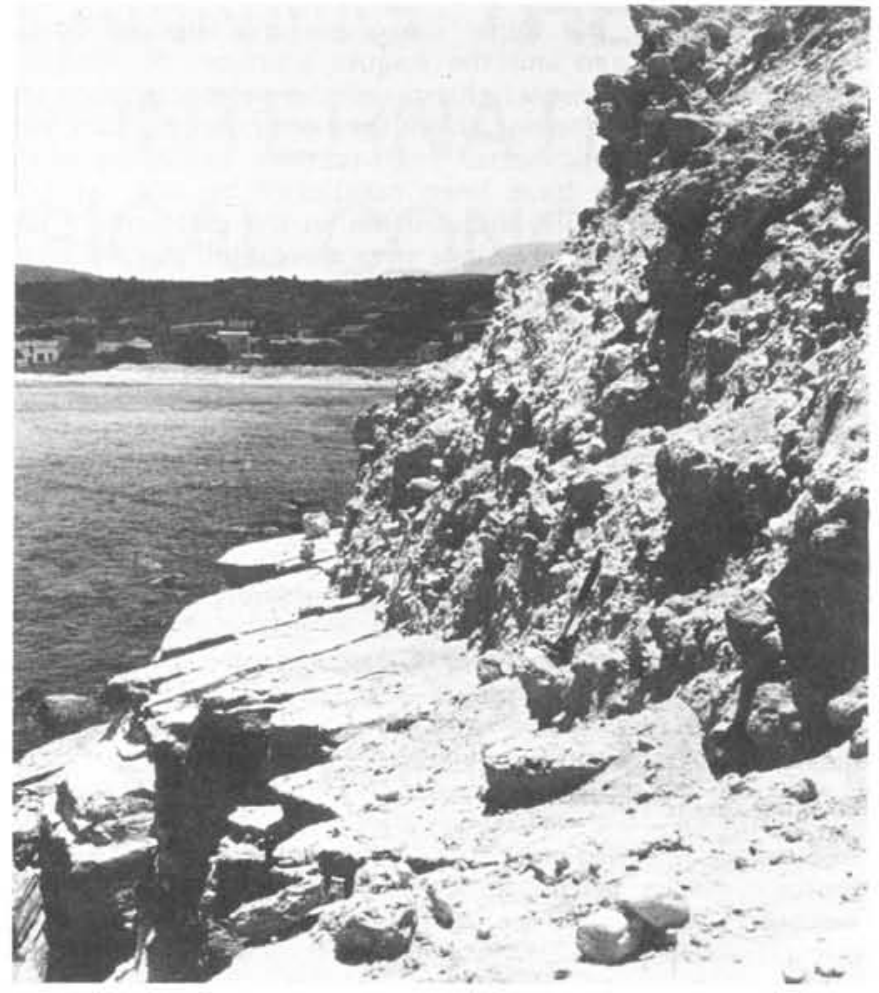

Figure 5. Lower Pliocene marl breccias and breccio-conglomerates unconformably overlying Lower Messinian limestones, Kalyves, western Crete. The mass-transported beds were deposited as a consequence of block-faulting shortly after the beginning of the Pliocene.

extending from the Alpine fore-deep in western Europe to Lake Aral in Central Asia (Baldi, 1980). As in the Mediterranean proper, the late Early Miocene movements resulted in a dramatic change in the paleogeography of the Paratethys. Thrusting caused the emplacement of nappe systems; the seaway connection between the Paratethys and the Mediterranean across southern France was definitely interrupted (Steininger and Rögl, 1979; Vass and Senes, 1975).

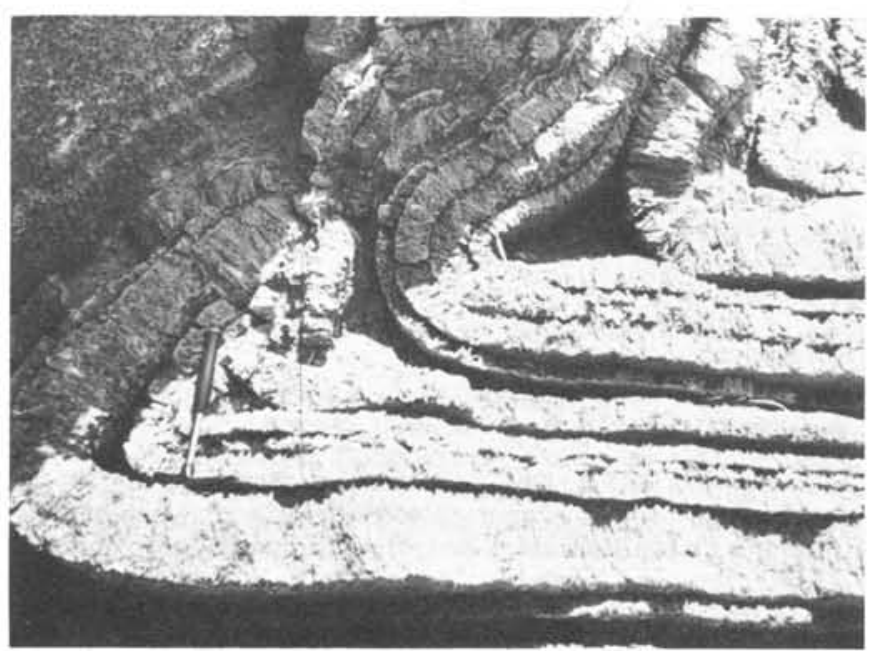

Figure 6. Strongly folded selenitic gypsum of Messinian Age, Eraclea Minoa, Sicily. The folding resulted from large-scale gravity sliding which started shortly after the beginning of the Pliocene (Photo courtesy H. Laagland) 
Data on the Oligocene to Pliocene history of Egypt (El-Heiny, in press) and on the Upper Oligocene and Miocene of the Maltese archipelago and the Ragusa platform of SE Sicily suggest that fundamental changes in the paleogeography and sedimentation on external platforms were contemporary with those in the orogenic belts. High tectonic instability in the orogenes seems to have been parallelled by low rates of sedimentation or uplift and erosion on the platforms. Subsequent regional transgressions were associated in some cases with a shift from carbonatic to terrigenous-clastic sedimentation on the platforms.

It is possible, therefore, to envisage a tentative model in which the contemporaneity of major geotectonic events causes a pulsating evolution of the Mediterranean-Paratethyan realm. Large-scale changes in the paleogeography and in the sedimentation patterns connected with this pulsating evolution were possibly not only episodic, but even periodic. This can be deduced from the clustering of the most important changes in sedimentary-tectonic "regimes" around $37,31,24,18,12$ and 5 million years ago (Fig. 2). The supposedly periodic character of major tectonic events does not necessarily imply periodicity of the underlying geodynamic processes, for example, of relative rates of plate movements, but periodicity cannot be ruled out.

\section{Looking Ahead}

Additional data are needed to discover whether the major tectonic events in the Mediterranean had worldwide counterparts. The same holds for research focussed on the interrelation between tectonic events and global, eustatic sea-level changes. At least some of the major and minor unconformities indicated in cycle-charts of global sea-level fluctuations (Vail and Hardenbol, 1979) seem to be synchronous with tectonic events in the Mediterranean-Paratethyan realm.

The relation between geodynamic events and the distribution of faunal and floral elements in time and space is another intriguing problem. Many conspicuous changes in the Mediterranean biorecord depended on changes in the paleogeography and paleoenvironmental conditions, changes which were basically controlled by geodynamic events. Therefore, the Mediterranean provides unique possibilities for pursuing research on the close interrelation between events in the lithosphere, the hydrosphere, the atmosphere and the biosphere.

\section{Acknowledgements}

The author wishes to thank B.W.M. Driever, P. Spaak, S. Theodoridis and W.J. Zachariasse for their biostratigraphic analyses of some sections; H. de Boorder, J.A. Broekman, C.W. Drooger, P. Marks, A.J. Romein, W.J. Zachariasse and G.J. van der Zwaan for critically reading the manuscript. The drawings and photographs were done by A. van Doorn and W. den Hartog; S.N. McNab has made some linguistic improvements.

\section{References}

Angelier, J., 1979, Néotectonique de l'Arc Egéen: Publ. Soc. Géol. du Nord, v. 3, p. 1-417.

Aubouin, J., 1973, Des tectoniques perposées et de leur signification par rapport aux modèles géophysiques: l'exemple des Dinarides; paléotectonique, tectonique, tarditectonique, néotectonique: Bull. Soc. Géol. France, Series 7, v. 15, no. 5-6, p. 426-460.

Baldi, T., 1980, The Early History of the Paratethys: Bull. Hungarian Geol. Soc., v. 110, p. 456-472.

Bizon, G. and Müller, C. (with Borsetti, A.M., Caulet, J.P., Gersonde, R., d'Onofrio, S. and Sokac, A.), 1979, Report of the working group on Mikropaleontology: Ann. Géol. Pays Hellén., Tome hors série, v. 3, p. 1335-1364.

Caire, A., 1973, The Calabro - Sicilian Arc, in de Jong, K.A. and Scholten, R. (eds.), Gravity and Tectonics: Wiley and Sons, New York. p. 157-173.

Closs, H., Roeder, D., Schmidt, K. (eds.), 1978, Alps, Apennines, Hellenides: Schweizerb. Verlagsbuchh., Stuttgart, p. 1-620.

Dercourt, J., Aubouin, J., Savoyat, E. et al., 1977, Réunion extraordinaire de la Société géologique de France en Grèce: Bull. Soc. Géol. France, Series 7, v. 19, no. 1, p. 5-70.

El-Heiny, I., in press, Neogene Stratigraphy of Egypt: Newsl. Stratigraphy, Berlin-Stuttgart.

Hardenbol, J. and Berggren, W.A., 1978, A new Paleogene numerical time-scale: In: Cohee, G.V., Glaessner, M.F., and Hedberg, H.D. (eds), Contributions to the geologic time scale. AAPG Stud. Geol., v. 6, p. 213-234.

Le Pichon, X. and Angelier, J., 1979, The Hellenic Arc and Trench system: A Key to the Neotectonic evolution of the eastern Mediterranean area: Tectonophysics, v. 60, no. 1/2, p. 1-42.

Meulenkamp, J.E., in press, The Hellenic and Calabro-Sicilian arcs - a comparative study: Proceed. Intern. Symp. Hell. Arc and Trench, Athens, 1981.

Ogniben, L., 1969, Schema introduttivo alla Geologia del Confine Calabro - Lucano: Mem. Soc. Geol. Ital., v. 8, p. 453-763.

Ogniben, L. and Vezzani, L., 1975, Nappe structure in Sicily, Calabria and Lucania, Italy, in Squyres, C.H. (ed.), Geology of Italy: Earth Sc. Soc. Lib. Ar. Rep., Tripolis, v. 2, p. 83-104.

Steininger, F. and Rögl, F., 1979, The Paratethys History - A contribution towards the Neogene Geodynamics of the Alpine Orogene (An Abstract): Ann. Géol. Pays Hellén., Tome hors série, v. 3, p. 1153-1165.

Vail, P.R. and Hardenbol, J., 1979, Sea-Level Changes during the Tertiary: Oceanus, v. 22, no. 3, p. 71-79.

Vass, D. and Senes, J. (eds.) 1975, Marine Neogene in Austria and Czechoslovakia, Excursion A, VIth Congr. Reg. Comm. Mediterr. Neog. Stratigr.: Veda, Publ. House Slovak Ac. Scienc., Bratislava, p. 1-183.

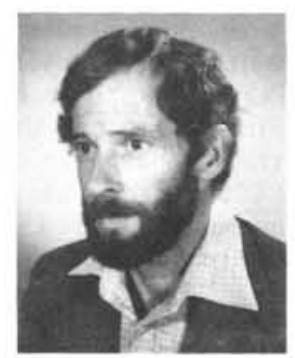

\section{ABOUT THE AUTHOR}

A senior Lecturer in the Department of Stratigraphy and Micropaleontology, University of Utrecht, the Netherlands, Dr. Johan E. Meulenkamp is actively involved in stratigraphic studies of the Mediterranean Tertiary. He is the Netherlands correspondent for the IGCP Project 25 "Stratigraphic Correlation of the Tethys-Paratethys Neogene", a member of the IUGS Subcommission on Neogene Stratigraphy, and President of the Regional Committee on Mediterranean Neogene Stratigraphy. 